Article

\title{
Spatial and Temporal Investigation of Dew Potential based on Long-Term Model Simulations in Iran
}

\author{
Nahid Atashi 1,2, Dariush Rahimi ${ }^{1}$, , Behnam M. Goortani ${ }^{3}$, Jonathan Duplissy ${ }^{2}$, \\ Henri Vuollekoski ${ }^{2}$, Markku Kulmala ${ }^{2}$, Timo Vesala ${ }^{2,4}$ and Tareq Hussein ${ }^{2,5, * \mathbb{D}}$ \\ 1 Department of Physical Geography, Faculty of Geographical Science and Planning, University of Isfahan, \\ Isfahan 8174673441, Iran; n.atashi@geo.ui.ac.ir or nahid.atashi@helsinki.fi \\ 2 Faculty of Science, Institute for Atmospheric and Earth System Research (INAR/Physics), \\ University of Helsinki, FI-00014 Helsinki, Finland; jonathan.duplissy@helsinki.fi (J.D.); \\ henri.vuollekoski@gmail.com (H.V.); markku.kulmala@helsinki.fi (M.K.); timo.vesala@helsinki.fi (T.V.) \\ 3 Department of Renewable Energy Engineering, Faculty of Advanced Sciences and Technologies, \\ University of Isfahan, Isfahan 8174673441, Iran; b.mostajeran@ast.ui.ac.ir \\ 4 Faculty of Agriculture and Forestry, Institute for Atmospheric and Earth System Research (INAR/Forest), \\ University of Helsinki, FI-00014 Helsinki, Finland \\ 5 School of Science, Department of Physics, University of Jordan, Amman 11942, Jordan \\ * Correspondence: d.rahimi@geo.ui.ac.ir (D.R.); tareq.hussein@helsinki.fi or t.hussein@ju.edu.jo (T.H.)
}

Received: 10 September 2019; Accepted: 20 November 2019; Published: 23 November 2019

\begin{abstract}
Since water shortage has been a serious challenge in Iran, long-term investigations of alternative water resources are vital. In this study, we performed long-term (1979-2018) model simulation at seven locations (costal, desert, mountain, and urban conditions) in Iran to investigate temporal and spatial variation of dew formation. The model was developed to simulate the dew formation (water and ice) based on the heat and mass balance equation with ECMWF-ERA-Interim (European Centre for Medium-Range Weather Forecasts-Re-Analysis) meteorological data as input. According to the model simulation, the maximum mean yearly cumulative dew yield $\left(\sim 65 \mathrm{~L} / \mathrm{m}^{2}\right)$ was observed in the mountain region in the north part of Iran with a yearly mean cumulative dew yield was $\sim 36 \mathrm{~L} / \mathrm{m}^{2}$. The dew yield showed a clear seasonal variation at all selected locations with maximum yields in winter (mean monthly cumulative $3-8 \mathrm{~L} / \mathrm{m}^{2}$ depending on the location). Here we showed that dew formation is frequent in northern Iran. In other areas, where there was suffering from water-stress (southern and central parts of Iran), dew can be a utilized as an alternative source of water. The dew yield during 2001-2014 was lower than the overall mean during the past 40 years a result of climate change in Iran.
\end{abstract}

Keywords: mass-heat balance; condensation; desublimation; semi-arid; seasonal; climate impact

\section{Introduction}

With increasing population growth rate and industrialization activities, the world's water supplies are being taxed to their capacity [1]. There has been a severe lack of fresh water in the world; especially in developing countries. Along with the deterioration of existing water supplies and increasing demand on water consumption it is expected that two-thirds of the population will lack sufficient fresh water by the year 2025 [2].

The atmosphere is a huge reservoir of water vapor, which is available everywhere and can be extracted by different methods (e.g., dew harvesting). Interestingly, it has been estimated that the global water content in the atmosphere is about $14000 \mathrm{~km}^{3}$ but the amount of fresh water in the earth is only about $1200 \mathrm{~km}^{3}$ [3]. Nevertheless, to face water shortage and rising water demand, the use of 
alternative sources of water has been tested over the last 20 years [4]. Harvesting moisture from the air can take in two forms: Fog and dew [5,6].

Dew occurs when a surface temperature is cooled (by losing heat to the sky via radiation) below the dew point temperature of the surrounding air; and thus, water condenses and accumulates on the surface [6]; usually, it occurs overnight. Under natural conditions, dew is a precious source of water for plants and animals in arid and semi-arid environments, where other sources of water such as rain and groundwater are very scarce $[1,7,8]$. In general, dew occurs infrequently and the harvested amounts are sometimes very small, but in some regions dew occurs frequently with significant amounts that can be utilized for human use [9-13].

Temporal and spatial occurrence of dew has been tested in many environments and by using different types of condensers (i.e., surfaces) [10-13]. These condensers are made of suitable materials and are basically thermally isolated from the ground [14-16]. As an empirical result, it is possible to increase the amount harvested dew water by utilizing the most suitable method [9,17-28]. However, empirical investigation of dew occurrence is cumbersome and laborious; therefore, modelling tools have been developed to simulate and predict dew potential over a large scale in real time $[25,29]$.

Mode simulations based on long-term periods can lead to better understanding about the dew formation and its relation with climate change trends. Modelling tools are also very useful for countries with limited resources of water (e.g., semi-arid regions such as Iran, which lies within the Asian arid/semi-arid belt). The average rainfall in Iran is about $250 \mathrm{~mm}$, which is less than one third of the global average $(850 \mathrm{~mm})$ [30]. The rainfall has a spatial distribution in Iran; and thus, the situation is even worse in desert areas with the average rainfall being less than $50 \mathrm{~mm}$. Water shortage stress, has been a serious challenge in many areas of Iran. Finding a complementary or alternative source of water resources is vital in Iran. In practice, there has been a lack of studies about the potential of dew formation in Iran. Only a few studies focused on fog as an alternative source of water [31,32]. Besides that, climate change has impacted the environment in Iran that has been reflected by decreased amounts of rainfall, rapid desertification, and loss of surface water areas [33-36].

In this study, we utilized a numerical model to investigate the spatial and temporal dew formation potential in selected areas in Iran: Coastal, mountain, urban, arid, and semi-arid areas. The model that we utilized was based on energy balance and was originally developed for a global scale [29]; here, the model was adopted to a domain for Iran and applied for a long-term period (1979-2018). We foresee the output of this study being useful for managing and planning for the feasibility of dew harvesting in Iran. Besides that, using long-term series in this study can show the temporal variation of dew formation, which could be associated with climate change.

\section{Materials and Methods}

We utilized a global dew formation model as previously described by Vuollekoski et al. [29]. This global model was setup to accommodate a domain (grid resolution 0.25 degree) that contains Iran. We performed the model simulations for a long-term period during 1979-2018 (40 years). We considered seven locations at selected stations in Iran representing three distinguished conditions: Mountains, desert, urban, and coastal (Figure 1 and Table 1). The detailed model description is found in the Supplementary Material (Section S1).

The model required a meteorological database as input. This included horizontal and vertical wind components $\left(U_{10}\right.$ and $\left.V_{10}\right)$ at $2 \mathrm{~m}$, surface roughness $\left(z_{0}\right)$, ambient temperature and dew point $\left(T_{a}\right.$ and $\left.D_{P}\right)$ at $2 \mathrm{~m}$, and short-wave and long-wave surface solar radiation $\left(R_{s w}\right.$ and $\left.R_{l w}\right)$. These were obtained from the European Centre for Medium Range Weather Forecast (ECMWF) Interim Reanalysis. ERA-Interim is a reanalysis of the global atmosphere covering the data-rich period since 1979 and continuing in real time [37,38], which has a horizontal resolution of $0.75^{\circ}$ (approximately $80 \mathrm{~km}$ ) and 60 vertical levels. The reanalysis combines available data sources (satellite, radiosondes, air craft, buoy data, stations etc.) into a coherent and balanced form of the atmospheric dynamic and 
thermodynamic state [39]. The details about the model input parameters and their processing is found in the Supplementary Material (Section S2).

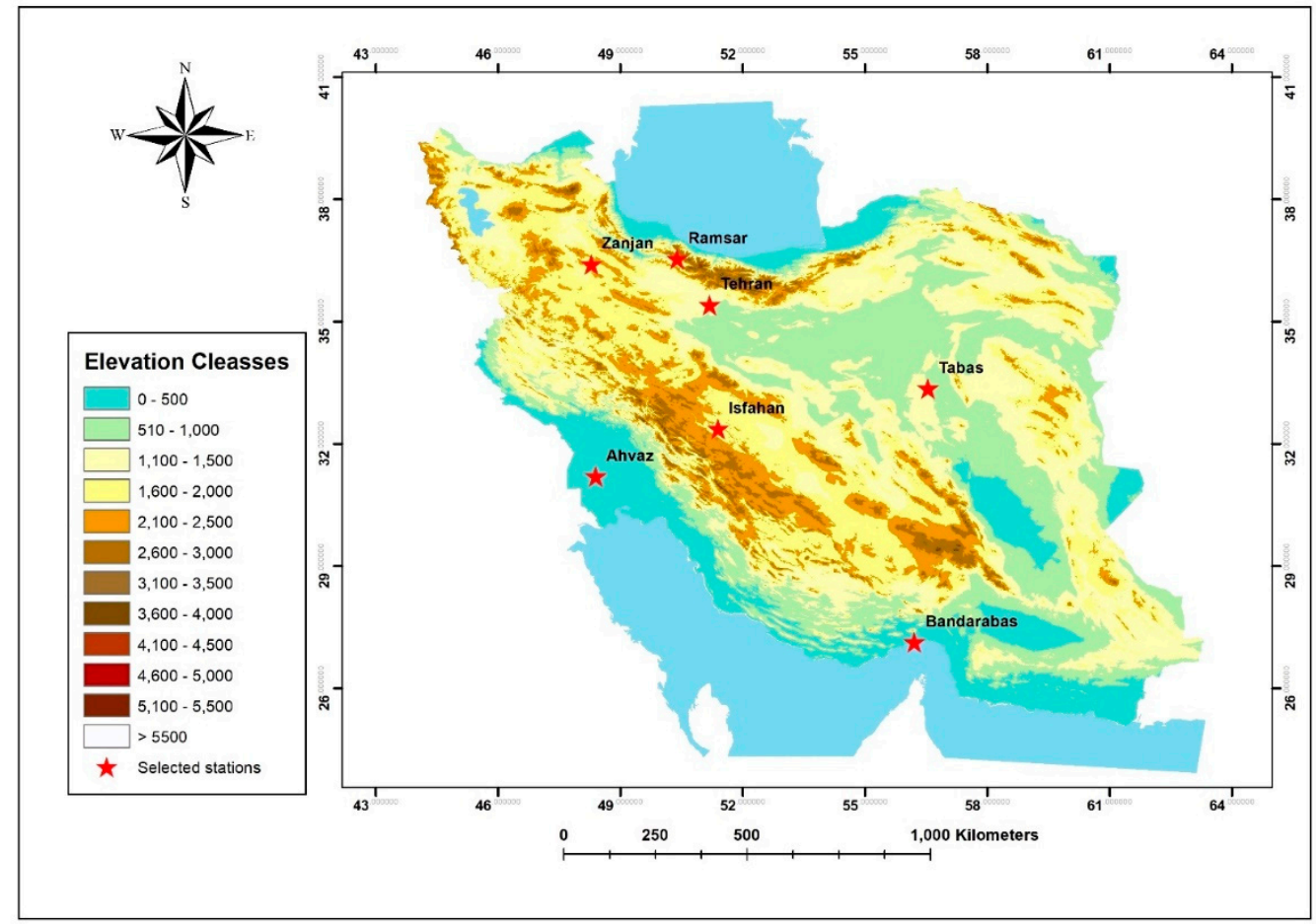

Figure 1. A map of Iran illustrating the geographical topography and the selected locations, where the model simulations were made for dew formation potential.

Table 1. Overall summary of the important parameters for the dew formation. This table was generated by utilizing synoptic data observed at the selected station.

\begin{tabular}{lccccc}
\hline \multicolumn{1}{c}{ Location } & Elevation $[\mathrm{m}]$ & $\boldsymbol{T}_{\boldsymbol{a}}\left[{ }^{\circ} \mathbf{C}\right]$ Mean (Min-Max) & $\boldsymbol{D P}\left[{ }^{\circ} \mathbf{C}\right]$ & $\boldsymbol{R} \boldsymbol{H}[\%]$ & Precipitation [mm/year] \\
\hline Ahvaz & 23 & $26(19-33)$ & 9 & 41 & 234 \\
Bandarabas & 9 & $27(22-32)$ & 19 & 66 & 182 \\
Isfahan & 1550 & $17(10-24)$ & -1 & 36 & 130 \\
Ramsar & -20 & $16(13-19)$ & 13 & 84 & 1188 \\
Tabas & 711 & $23(16-29)$ & 2 & 31 & 60 \\
Tehran & 1191 & $18(13-23)$ & 2 & 41 & 242 \\
Zanjan & 1663 & $11(4-18)$ & 0 & 54 & 298 \\
\hline
\end{tabular}

\section{Results}

\subsection{Examples of a Detailed Model Simulation Output}

In order to show the detailed model output results, we selected three examples: Bandarabas (south and costal) during 2-6 January 2005, Ramsar (middle and desert) during 1-5 September 2011, and Tabas (central and desert) during 12-15 December 2002 (Figures S1-S3). The selected time periods of these examples were based on the model simulation results to choose a period with maximum dew yield. Besides the model simulation output, which includes dew yield and temperature of the condenser sheet $\left(T_{\mathcal{C}}\right)$, Figures S1-S3 also show the corresponding model input: Long-wave radiation $\left(R_{\mathrm{lw}}\right)$, short-wave radiation $\left(R_{\mathrm{sw}}\right)$, wind speed $(W S)$, ambient temperature $\left(T_{\mathrm{a}}\right)$, and dew point $\left(D_{\mathrm{P}}\right)$.

In these examples, it is clearly shown that condensation occurs when $T_{\mathrm{C}}<D_{\mathrm{P}}$ and $W S$ is mostly less than $1 \mathrm{~m} / \mathrm{s}$. In general, at these stations the dew formation is expected to start in the evening (around 18:00) and continues to the next morning (until 06:00). During daytime, the incoming short-wave radiation from the sun as well as the atmospheric long-wave radiation increase the temperature of the 
condenser sheet, which prevents dew formation. In contrast, during nighttime, the outgoing thermal radiation exceeds the atmospheric long-wave radiation, which is greatly influenced by cloudiness. For example, the thermal emission by clouds, especially low clouds, increases the incoming thermal radiation at the surface.

\subsection{Yearly Variation of the Cumulative Dew Yield}

We calculated the yearly cumulative dew yield (Figure 2 and Table 2). The overall average of yearly cumulative dew yield in liquid form (i.e., water) was the highest in Ramsar (56 $\pm 4 \mathrm{~mm}$; north and mountains). Isfahan, Tehran, and Tabas had the lowest overall average value of yearly cumulative water dew yield as $13 \pm 3,11 \pm 4$, and $9 \pm 3 \mathrm{~mm}$, respectively. Isfahan and Tehran were arid regions whereas Tabas was a desert.

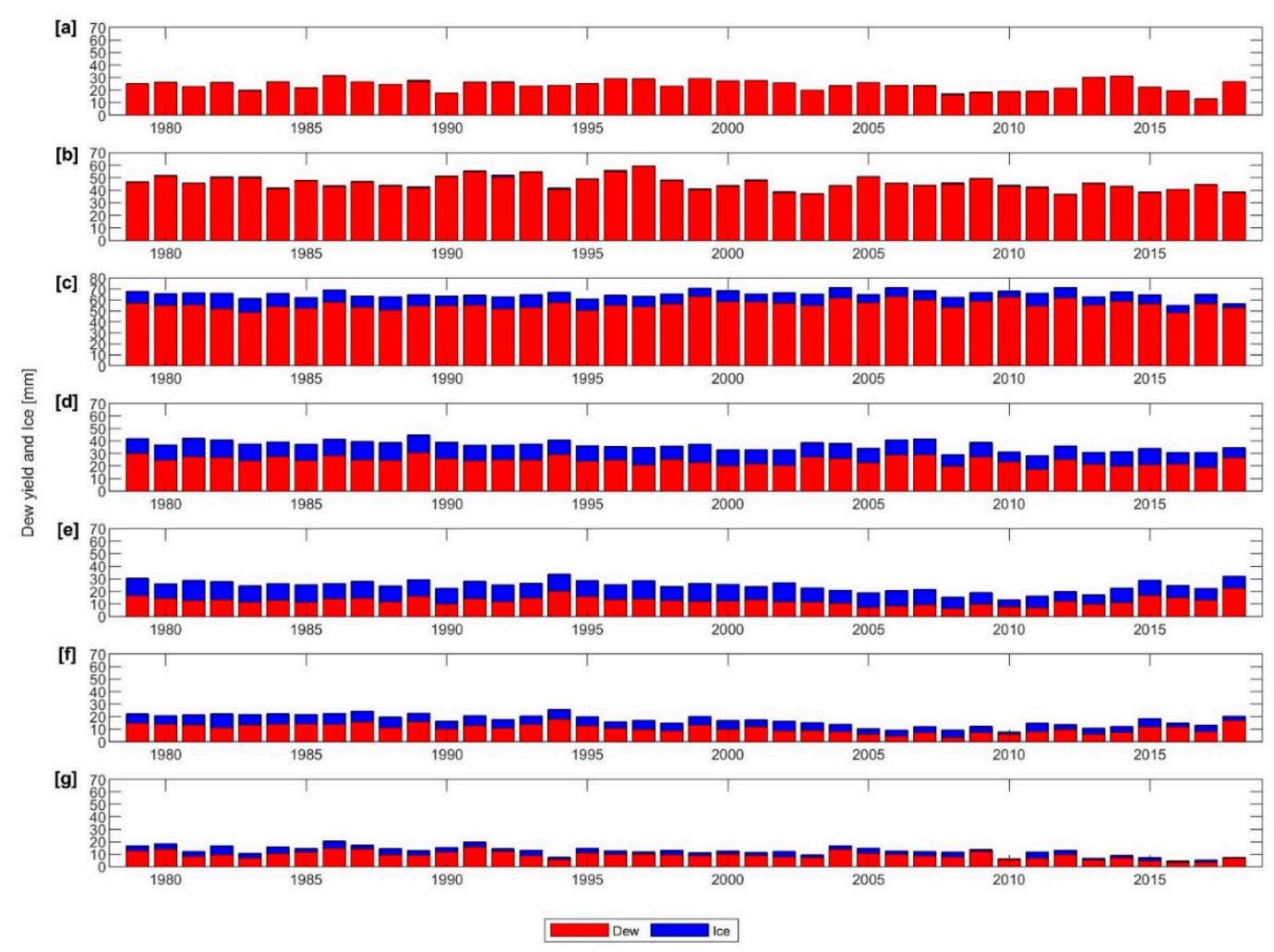

Figure 2. Yearly cumulative dew yield in water and ice forms during 1979-2018 at the selected stations: (a) Ahvaz; (b) Bandarabas; (c) Ramsar; (d) Zanjan; (e) Isfahan; (f) Tehran; and (g) Tabas.

Table 2. Overall mean \pm standard deviation as well as the range of the yearly cumulative dew yield. The values are listed as mean \pm standard deviation $[\mathrm{min}-\mathrm{max}]$ in $\mathrm{mm}$.

\begin{tabular}{lccc}
\hline \multicolumn{1}{c}{ Location } & Water & Ice & Water + Ice \\
\hline Ahvaz & $24.0 \pm 4.2[12.8-31.3]$ & $0.2 \pm 0.3[0.0-1.2]$ & $24.2 \pm 4.2[12.9-31.5]$ \\
Bandarabas & $45.5 \pm 5.3[36.4-59.1]$ & $0.6 \pm 0.3[0.1-1.5]$ & $46.2 \pm 5.3[36.9-59.5]$ \\
Isfahan & $12.5 \pm 3.3[6.2-22.4]$ & $12.0 \pm 2.2[5.6-16.1]$ & $24.4 \pm 4.5[13.3-33.7]$ \\
Ramsar & $55.8 \pm 3.7[48.4-63.2]$ & $9.6 \pm 2.0[3.8-14.4]$ & $65.3 \pm 3.5[55.1-71.4]$ \\
Tabas & $9.2 \pm 3.0[3.4-15.7]$ & $3.3 \pm 1.4[0.7-7.1]$ & $12.6 \pm 3.8[4.4-20.4]$ \\
Tehran & $10.8 \pm 3.5[3.5-18.0]$ & $6.5 \pm 1.8[1.7-11.2]$ & $17.3 \pm 4.6[7.9-25.7]$ \\
Zanjan & $24.4 \pm 3.3[17.2-30.6]$ & $12.1 \pm 1.7[7.9-14.8]$ & $36.5 \pm 3.9[28.4-44.7]$ \\
\hline
\end{tabular}

The conditions for dew in solid form (i.e., ice) was rarely met for Ahvaz and Bandarabas (Figure 2 and Table 2). Therefore, the overall average ice dew yield was very low in these two locations. The overall average of yearly cumulative ice dew yield was the highest in Zanjan and Isfahan (about 
$12 \pm 3 \mathrm{~mm}$ ), which were located in high elevation areas with mean dew point temperatures less than what could be found in other selected locations in this study (Table 1).

In general, there was not a clear long-term pattern in the water dew yield in Ahvaz, Bandarabas, Ramsar, and Zanjan. As for ice dew yield throughout the 40 years (1979-2018), it tends to decrease for all locations except for Ahvaz. Interestingly, the dew yield during 2001-2014 was less than the overall average in Isfahan and Tehran (Figure 3). Similarly, the dew yield in Tabas was less than the overall average during 2014 and onwards. This could be due to the climate change impacts in Iran. The decline in the dew yield during 2001-2014 is not surprising because it was due to climate change impacts and its consequences (increased desertification and increased potential of sand and dust storms) in Iran, which can be the same as what was observed in the Eastern Mediterranean $[33,34]$. For example, Notaro et al. [33] showed that the Eastern Mediterranean region has suffered from warming and drying episodes since 2000 that forced the Fertile Crescent (namely Iraq and Syria) to collapse. As such, the dried land in the Fertile Crescent increased dust generation and transport during 2007-2013, which has been characterized with an increased number of dust days, frequency of dust events, and atmospheric dust concentration in the atmosphere. In turn, this has had a significant impact on the albedo and short-wave radiation leading to higher surface reflection [35]. As a result, this could impact the potential of dew formation as indicated by our model simulation results.

[a]
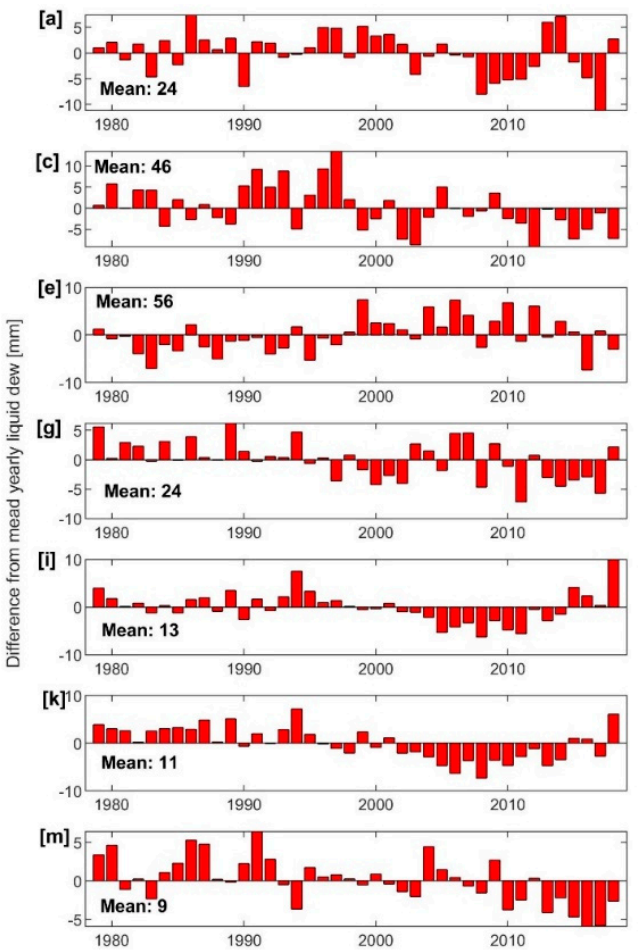

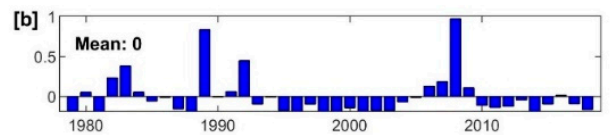

[d]
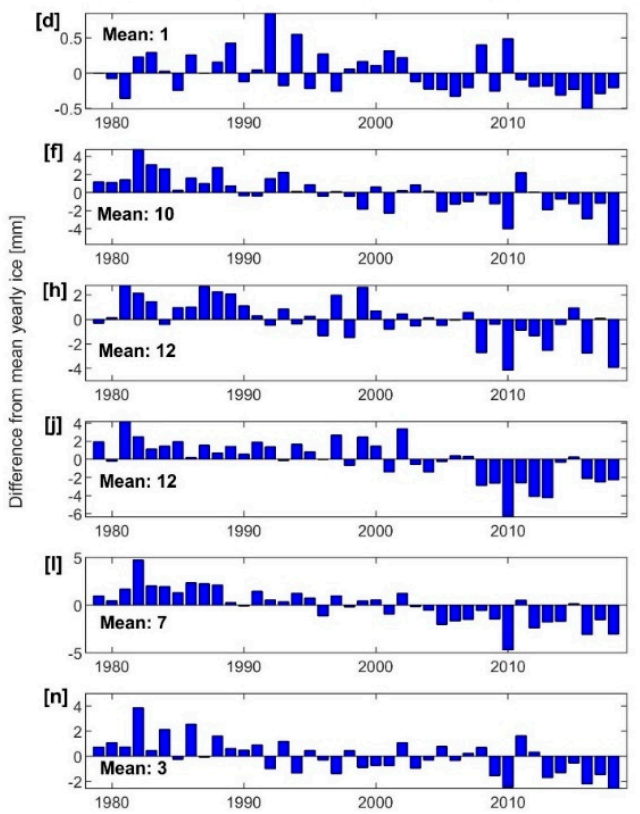

Figure 3. Difference between mean yearly cumulative dew yield in water form (left panel) and ice form (right panel) and yearly long-term mean during 1979-2018 at the selected stations: (a,b) Ahvaz; (c,d) Bandarabas; (e,f) Ramsar; (g,h) Zanjan; (i,j) Isfahan; (k,l) Tehran; and (m,n) Tabas.

\subsection{Seasonal Variation of the Cumulative Dew Yield}

Accordingly, to the mean monthly and mean daily cumulative dew yield, the dew has a seasonal cycle (Figures 4 and 5). The seasonal trend was rather similar in Ahvaz (dry but nearly coastal), Bandarabas (coastal), Isfahan (mountain surrounded by desert), Tehran (arid urban), and Tabas (desert). In these locations, the dew yield was at its maximum in December and January (about 7, 8, 4, 3, and $3 \mathrm{~L} / \mathrm{m}^{2}$ in Ahvaz, Bandarabas, Isfahan, Tehran, and Tabas, respectively). Furthermore, the period of potential dew formation in Bandarabas was the longest and it spanned from late August until late April. The shortest period of potential dew formation was in Ahvaz and it spanned from early 
November until the middle of April. In Isfahan, Tehran, and Tabas, the potential dew formation period started during October and ended during May. In general, in these locations, the amount of dew yield was maximum in winter and almost vanished during the summer. It can be also noticed from the model simulations that the solid phase (i.e., ice) of dew yield exceeded the liquid phase (i.e., water) during the winter in Zanjan, Isfahan, Tehran, and Ramsar.

The differences of dew yield seasonal cycle in the selected locations was expected to be due to differences in winter season start and end time as well as the environmental conditions including the relative humidity and difference between temperature and dew point temperature $\left(T-T_{d}\right)$. In addition, wind speed can play a role in stimulating dew formation. For example, in mountains the temperature is expected to decrease more rapidly than in the desert and costal locations. Vanishing dew yield in desert and coastal areas during summer was also expected because the dew point was very low for dew formation to occur even if the relative humidity was high (e.g., in Ahvaz and Bandarabas). Another reason could be due to the lack of water vapor in the atmosphere during the summer (e.g., in Isfahan, Tehran, and Tabas). Dew formation in spring and summer in Zanjan and Ramsar could be due to sustainability of the prevailing wind from the west in these areas especially in spring was accompanied by high relative humidity. In summer high relative humidity in Ramsar (as a coastal location) could compensate higher temperature at night. In contrast, in Zanjan (as a mountain location) low temperature during the nighttime could compensate for relative humidity, so that dew formation can continue even in summer in this location.
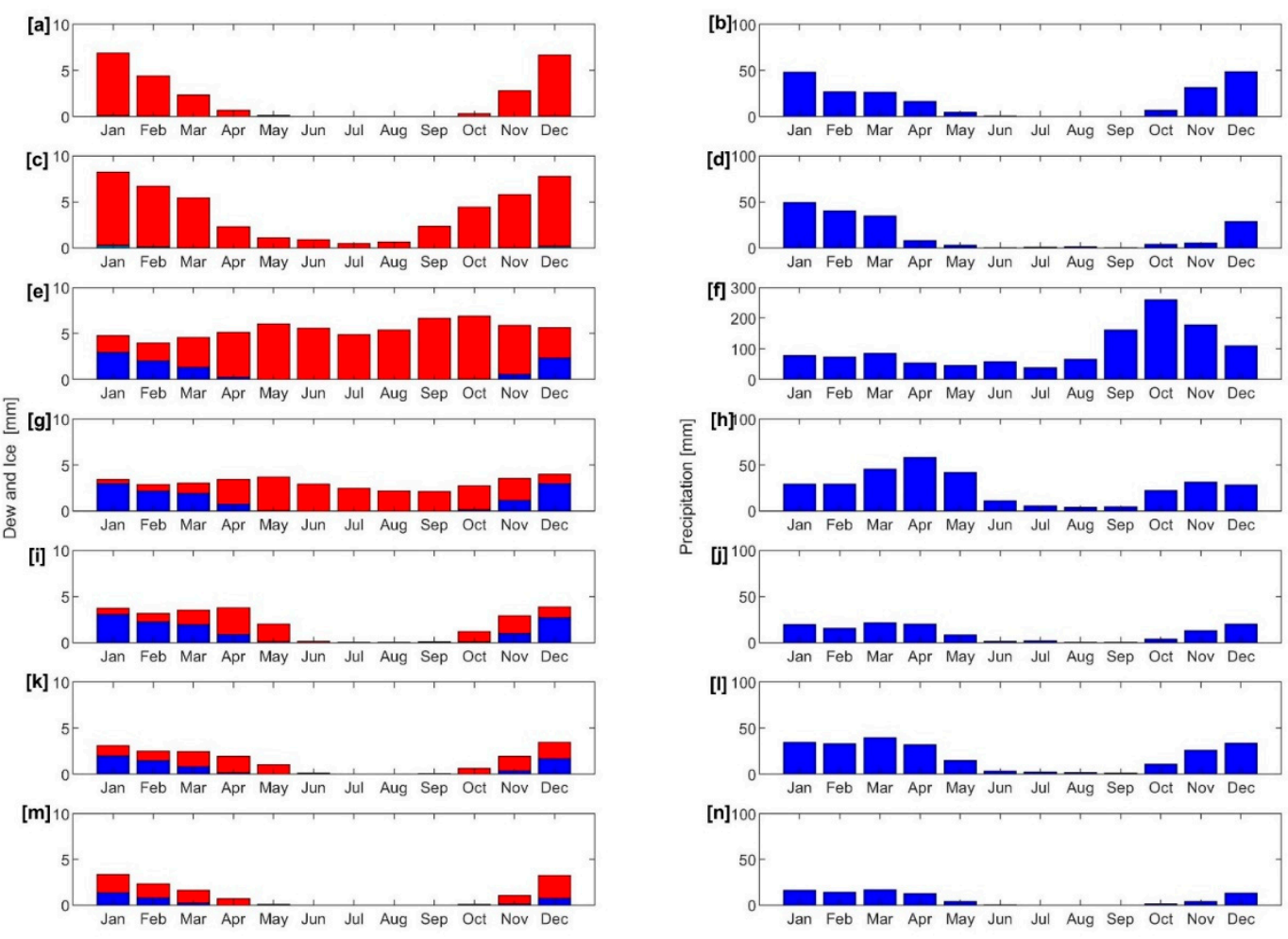

Figure 4. Mean monthly cumulative dew yield in water form (red) and ice form (blue) shown in the left panel and compared to the precipitation (right panel) at the selected stations during 1979-2018: (a,b) Ahvaz; (c,d) Bandarabas; (e,f) Ramsar; (g,h) Zanjan; (i,j) Isfahan; (k,l) Tehran; and (m,n) Tabas.

Furthermore, Ramsar (in north Iran), which was surrounded by mountains and close to the Caspian Sea, had the highest potential of dew formation in the autumn which can be explained by the Siberian high pressure in this season from north east of Iran. This air mass is extremely cold and dry but by passing through the Caspian Sea it becomes mild and due to lower temperature, relative humidity reaches its highest level and $T-T_{\mathrm{d}}$ decreases. Furthermore, wind speed was in its lowest level $\left(\sim 2 \mathrm{~m} \mathrm{~s}^{-1}\right.$ during night), which means that it was ideal conditions for dew formation in this season in 
northern areas in Iran (i.e., Ramsar). Interestingly, the lowest dew yield in Ramsar was during winter; one reason could be due to the dry and cold conditions accompanied with air masses from continental polar areas during the winter. Such air masses decrease the amount of moisture in the atmosphere that suppress the dew formation potential.
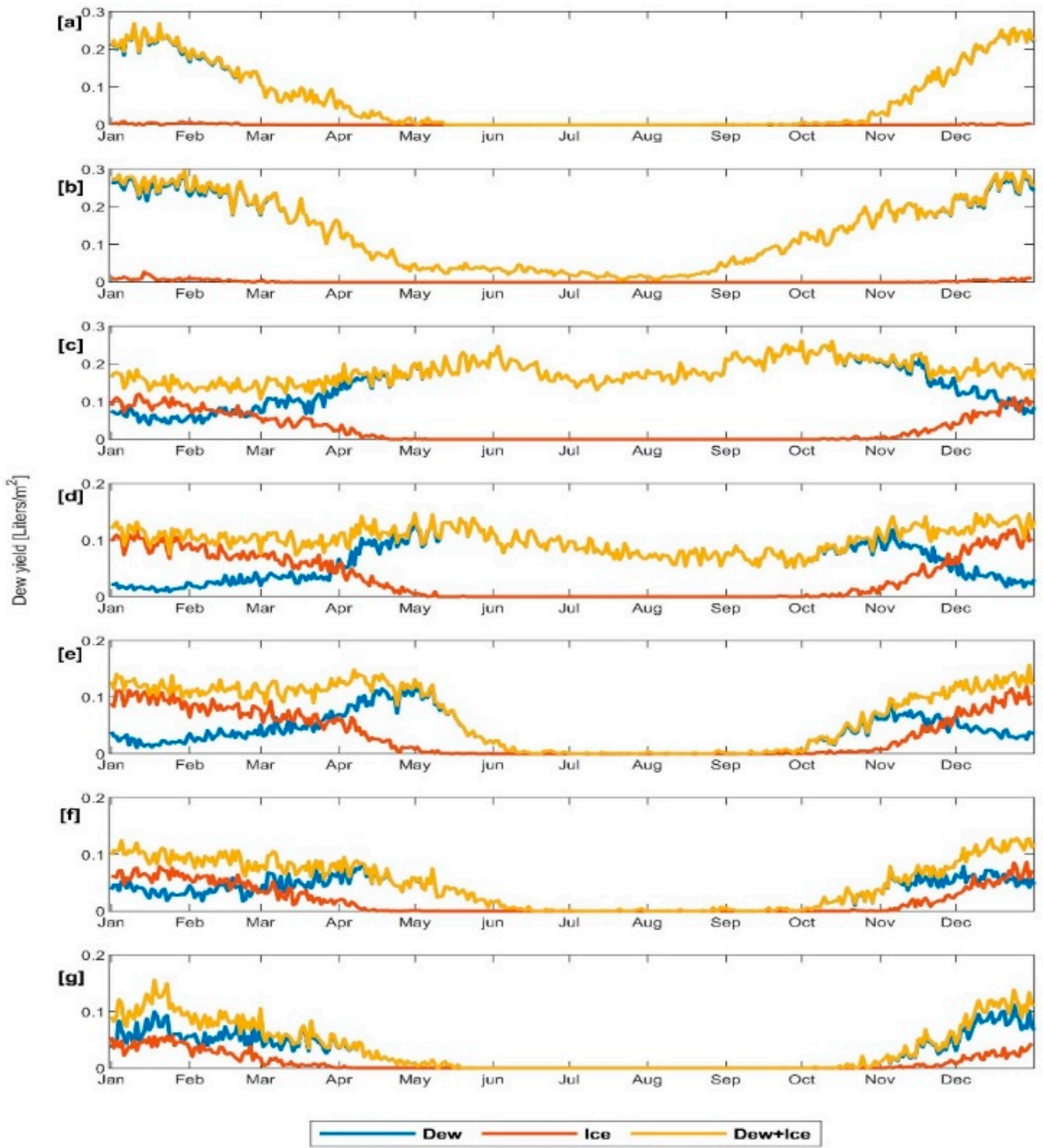

Figure 5. Mean daily cumulative dew yield (blue line), ice (red line) and dew+ice (yellow line) during 1979-2018 at the selected stations: (a) Ahvaz; (b) Bandarabas; (c) Ramsar; (d) Zanjan; (e) Isfahan; (f) Tehran; and (g) Tabas.

In comparison with monthly precipitation (Figure 4), the amount of dew yield was not as high as precipitation. However, in coastal and desert areas, dew formation could be a significant source of water as it yielded about $25 \%$ and $22 \%$ of precipitation in Bandarabas (coastal) and Tabas (desert), respectively. As for Isfahan, Zanjan, and Ahvaz, it was 19\%,12\%, and 10\%, respectively. The minimum amount (less than 10\%) was seen in Tehran (7\%) and Ramsar (5\%).

According to the mean daily cumulative dew yield (Figure 5), the yield was in Bandarabas $\left(\sim 0.30 \mathrm{~L} / \mathrm{m}^{2}\right)$ and Ahvaz $\left(\sim 0.27 \mathrm{~L} / \mathrm{m}^{2}\right)$ during December and January. In Isfahan and Tabas, it was $\sim 0.16 \mathrm{~L} / \mathrm{m}^{2}$ in December and January. The lowest was in Tehran $\left(\sim 0.13 \mathrm{~L} / \mathrm{m}^{2}\right.$ in December). The highest mean cumulative daily dew yield in Ramsar was in autumn $\left(\sim 0.26 \mathrm{~L} / \mathrm{m}^{2}\right.$ in October $)$ and in Zanjan it 
was in spring (May; $\sim 0.15 \mathrm{~L} / \mathrm{m}^{2}$ ). According to the mean cumulative daily dew yield, there is a potential for dew formation throughout the whole year in Zanjan and Ramsar. As for Bandarabas, Tehran, and Isfahan the potential period is about eight months and about six months in Ahvaz and Tabas.

\section{Discussion}

In order to gain insight on the dew potential in Iran, we shall compare to previous studies, especially those conducted on long-term bases and also those on model simulation [29].

Vuollekoski et al. [29] performed global model simulation by using the same model for the period of 34 years (1979-2012). They have shown that continental dew formation was common and frequent with daily dew yields $<0.1 \mathrm{~mm}$ (i.e., $\mathrm{L} / \mathrm{m}^{2}$ ). Furthermore, they showed that in water-stressed areas (e.g., coastal regions of northern Africa and the Arabian Peninsula) can have yearly cumulative yield as high as $100 \mathrm{~L} / \mathrm{m}^{2}$ (assuming polyethylene foil as the condenser surface material), which has a potential for large-scale dew harvesting.

Vuollekoski et al. [29] also focused on the Middle East as a semi-arid region (specifically, presented time series of dew yield in the Negev desert, where natural dew collection was reported [20,40-42]). The model results overestimated the dew yield in this region. A possible reason for this can be due to the differences between the model assumptions and the collection criteria; this might require model calibration for specific regions. Interestingly, their model simulation also predicted a decreasing trend during 2000-2012, which was the same period of decreased dew yield according to the model simulations in this study. As we discussed this before in Section 3.2, this can be due to the climate change impacts in the Middle East in the form of increased desertification and increased potential of sand and dust storms [33-35].

At another location in the Middle East, which was Beiteddine village (920 $\mathrm{m}$ above sea level along the mountain chain overlooking the eastern Mediterranean) in Lebanon, Tomaszkiewicz et al. [43] collected dew during the dry season (April-October) in 2013-2014. According to their method, the average nightly dew yield was $0.13 \mathrm{~L} / \mathrm{m}^{2}$ and a maximum daily yield of $0.46 \mathrm{~L} / \mathrm{m}^{2}$. They found out that dew events were more frequent than precipitation events and suggested that harvested dew can significantly impact diurnal soil moisture $(>3 \%)$ during evenings assuming average nightly dew yields more than $0.2 \mathrm{~L} / \mathrm{m}^{2}$. They further estimated that the dew amount (harvesting and storing by using a $2 \mathrm{~m}^{2}$ condenser) could be sufficient to irrigate tree seedlings (typically requiring $\sim 4.5 \mathrm{~L} /$ seedling every 30-40 days), which is a feasible option mitigating tree mortality during droughts or in arid or semi-arid regions.

Hanisch et al. [44] reported dewfall in a semi-arid coastal area in south-western Madagascar during April 2013-September 2014. The daily dew yield was in the range $0.06-0.19 \mathrm{~L} / \mathrm{m}^{2}$ with maxima reaching $0.48 \mathrm{~L} / \mathrm{m}^{2}$. According to their investigation, the dewfall was about $19 \%$ of annual rainfall. They further suggested that in the studied area, dewfall can play a role in the annual water balance, but its ecological significance remains to be investigated.

In the Absheron Peninsular (Baku, Azerbaijan), which is a neighboring country to Iran and has a similar climate (i.e., semi-arid), Meunier and Beysens [45] exploited dew, fog, drizzle, and rain water during April 2010-March 2011. The results showed that the amount of potential water can be 84, 15,6 , and $13 \mathrm{~mm}$; respectively in the form of rain, dew, fog, and drizzle. Therefore, they foresee a fair indication that collecting dew, fog, and drizzle in addition to rain can significantly increase the collected atmospheric water with value estimated on order $40 \% \pm 20 \%$.

Dewfall can be also considered as a substantial water resource in desert ecosystems. The hyper-arid zone of the Taklimakan Desert (China) is one example. Hao et al. [46] elucidated dew formation and its long-term trend in this region. Their results proved that dewfall can be one of important water resources in the arid Taklimakan Desert region. They showed that in the Populus forest dewfall duration was $\sim 2 \mathrm{~h}$ in the nighttime with an average of $\sim 0.12 \mathrm{~L} / \mathrm{m}^{2}$ (June-October 2011). The number of dewfall days was 104 days (73\% of total days), and the cumulative dewfall amount was $12.87 \mathrm{~L} / \mathrm{m}^{2}$. 
In other parts of the world, Gaiek et al. [47], presented a systematic review on dew yield from plane radiative condensers in various field campaigns during 1993-2010. The overall outcome of these campaign results showed that the mean daily dew yield was in the range $0.06-0.20 \mathrm{~L} / \mathrm{m}^{2}$. The maximum daily dew yield among those studies was in the range $0.08-0.60 \mathrm{~L} / \mathrm{m}^{2}$. These studies included regions with different environments and climate: Kungsbacka (Sweden); Dodoma (Tanzania); Brive-la-Gaillarde, Bordeaux, and Ajaccio (France); Osaka (Japan); Jerusalem (Israel); Komiza and Zadar (Croatia); Central Netherlands; Tahiti; Tikehau; South-West Morocco; and Wrocław and Sudetes (Poland) [14,17,18,25,47-57].

The world's largest dew and rain collecting system was constructed in 2006 at Panandhro in the semi-arid area of Kutch, North-West India [58]. It comprised of 10 ridge-and-trough modules with a net surface area $850 \mathrm{~m}^{2}$. The ultimate goal aimed at collecting dew on a scale that could be beneficial to the local population. For 192 days, the system collected a cumulated amount of dew water of $\sim 12.6 \mathrm{~L} / \mathrm{m}^{2}$ with a maximum of $0.56 \mathrm{~L} / \mathrm{m}^{2}$ per night. The output for 2007 was $6545 \mathrm{~L}$, which corresponded to $7.7 \mathrm{~mm} /$ day on average. The chemical and biological analyses showed that dew water, once filtered and bottled, could be used for drinking after a light treatment to increase the $\mathrm{pH}$.

\section{Conclusions}

Water resources have been a challenge, especially when it comes to potable water in arid and semi-arid regions. Recently, water shortage in the Iran has an increased socioeconomic impact. As such, alternative sources of water have become more and more urgent. Artificially induced dew formation and harvesting can be one of the solutions as an alternative water source. In practice, investigations of the temporal and spatial variation based on long-term database and model simulations of dew potential is an important step towards utilization of dew harvesting in the future.

In this study, we performed a long-term model simulation over 40 years (1979-2018) aiming at investigating the temporal and spatial variation of dew yield potential at seven locations (costal, desert, mountain, and urban conditions) in Iran. The model described the dew yield via condensation and desublimation on a thermally insulated and horizontally aligned sheet at a height of $2 \mathrm{~m}$ from the ground. The model is based on the heat and mass balance equation with ECMWF-ERA-Interim meteorological database as an input.

According to the model simulation, the maximum mean yearly cumulative dew yield $\left(\sim 65 \mathrm{~L} / \mathrm{m}^{2}\right)$ was observed in the coastal area Ramsar. In the mountain area Zanjan, the yearly mean cumulative dew yield was $\sim 36 \mathrm{~L} / \mathrm{m}^{2}$. The dew yield showed a clear seasonal variation at all stations. In general, the maximum dew yield was maximum in winter (mean monthly cumulative; $7,8,4,4,3$, and $3 \mathrm{~L} / \mathrm{m}^{2}$ for Ahvaz, Bandarabas, Isfahan, Zanjan, Tehran, and Tabas, respectively). As for the coastal area Ramsar, the highest dew yield was observed in autumn $\left(\sim 7 \mathrm{~L} / \mathrm{m}^{2}\right)$ and, unexpectedly, the lowest was in winter. Based on this modelling study, dew formation was found to be common and frequent, in some areas where other source of water exists (i.e., Ramsar and Zanjan). In other areas, where there was suffering from water-stress (south and center areas), especially those with dry season (summer or in some areas also spring), dew was also absent.

Compared to the annual cumulative precipitation, the dew yield percentage can be $5-25 \%$ depending on the geographical location of the station and season. In a semi-arid region such as Iran, this percentage can be a good alternative source of water for agriculture.

According to the model simulation results, the dew yield during 2001-2014 was lower than the overall mean during the past 40 years. This was a result of climate change impacts that increased desertification, reduced precipitation, and shrank surface water areas in Iran.

Supplementary Materials: Model description and nomenclature are available online at http://www.mdpi.com/ 2073-4441/11/12/2463/s1. Table S1: Description of the dew formation model by listing the terms in Equation (1), Table S2: A list of nomenclature, Figure S1: An example model simulation for dew formation during 2-6 January 2005 at Bandarabas, Iran. (a) the short-wave and long-wave radiation (left y-axis) and wind speed (right y-axis) whereas (b) the cumulative dew formation on the condenser (bars linked to the y-axis right axis) and the ambient temperature, dew point, and condenser sheet temperature (left y-axis), Figure S2: An example model simulation 
for dew formation during 1-5 September 2011 at Ramsar, Iran. (a) the short-wave and long-wave radiation (left $\mathrm{y}$-axis) and wind speed (right y-axis) whereas (b) the cumulative dew formation on the condenser (bars linked to the y-axis right axis) and the ambient temperature, dew point, and condenser sheet temperature (left y-axis), Figure S3: An example model simulation for dew formation during 12-15 December 2002 at Tabas, Iran. (a) the short-wave and long-wave radiation (left y-axis) and wind speed (right y-axis) whereas (b) the cumulative dew formation on the condenser (bars linked to the y-axis right axis) and the ambient temperature, dew point, and condenser sheet temperature (left y-axis).

Author Contributions: Conceptualization, D.R., T.H., B.M.G. and N.A.; methodology, H.V. and N.A.; validation, N.A. and T.H.; formal analysis, N.A. and T.H.; investigation, N.A.; resources, T.V. and M.K.; data curation, N.A.; writing — original draft preparation, N.A. and T.H.; writing-review and editing, N.A., T.H., D.R., T.V. and J.D.; visualization, N.A. and T.H.; supervision, D.R., T.H., T.V.; project administration, D.R., T.H., and T.V.

Funding: This research received no external funding.

Acknowledgments: The University of Isfahan is acknowledged to facilitate the research visit abroad for graduate students. The Ministry of Science, Research, and Technology supported Miss Nahid Atashi to visit the University of Helsinki, Institute for Atmospheric and Earth System Research (UHEL-INAR). The University of Helsinki hosted Miss Atashi twenty months of her research visit working on dew yield potential modeling. This visit was also under the Academy of Finland Center of Excellence programme (CoE-ATM, grant no. 307331) and Academy Professor projects (312571 and 282842). This manuscript was written and completed during the sabbatical leave of the last author (Tareq Hussein) that was spent at the University of Helsinki and supported by the University of Jordan during 2019. Open access funding provided by University of Helsinki.

Conflicts of Interest: The authors declare no conflict of interest.

\section{References}

1. Rajvanshi, A.K. Large scale dew collection as a source of fresh water supply. Desalination 1981, 36, $299-306$. [CrossRef]

2. Lindblom, J.; Nordell, B. Water production by underground condensation of humid air. Desalination 2006, 189, 248-260. [CrossRef]

3. Hamed, A.M.; Kabeel, A.E.; Zeidan, E.S.B.; Aly, A.A. A technical review on the extraction of water from atmospheric air in arid zones. Heat. Mass. Trans. 2010, 4, 213-228.

4. Lekouch, I.; Muselli, M.; Kabbachi, B.; Ouazzani, J.; MelnytchoukMilimouk, I.; Beysens, D. Dew, fog, and rain as supplementary sources of water in southwestern Morocco. Energy 2011, 36, 2257-2265. [CrossRef]

5. Mileta, M.; Beysens, D.; Nikolayev, V.; Milimouk, I.; Clus, O.; Muselli, M. Fog and Dew Collection Projects in Croatia. Available online: https://arxiv.org/ftp/arxiv/papers/0707/0707.2931.pdf (accessed on 22 November 2019).

6. Raman, C.R.V.; Venkatraman, S.; Krishnamurthy, V. Dew ver India and Its Contribution to Winter-Crop Water Balance. Agric. For. Meteorol. 1973, 11, 17-35. [CrossRef]

7. Kidron, G.J.; Herrnstadt, I.; Barzilay, E. The role of dew as a moisture source for sand microbiotic crusts in the Negev Desert, Israel. J. Arid Environ. 2002, 52, 517-533. [CrossRef]

8. MaestreValero, J.F.; MartinezAlvarez, V.; Baille, A.; MartínGórriz, B.; GallegoElvira, B. Comparative analysis of two polyethylene foil materials for dew harvesting in a semiarid climate. J. Hydrol. 2011, 410, 84-91. [CrossRef]

9. Sharan, G. Dew Yield from Passive Condensers in a Coastal Arid Area: Kutch. Available online: http: //vslir.iima.ac.in:8080/jspui/bitstream/11718/6362/1/2005-01-05gsharan.pdf (accessed on 22 November 2019).

10. Nilsson, T.M.J.; Vargas, W.E.; Niklasson, G.A.; Granqvist, C.G. Condensation of water by radiative cooling. Ren. Energy 1994, 5, 310-317. [CrossRef]

11. Jumikis, A.R. Aerial wells: Secondary source of water. Soil Sci. 1965, 100, 83-95. [CrossRef]

12. Nikolayev, V.S.; Beysens, D.; Gioda, A.; Milimouka, I.; Katiushin, E.; Morel, J.P. Water recovery from dew. J. Hydrol. 1996, 182, 19-35. [CrossRef]

13. Khalil, B.; Adamowski, J.; Shabbir, A.; Jang, C.; Rojas, M.; Reilly, K.; OzgaZielinski, B. A review: Dew water collection from radiative passive collectors to recent developments of active collectors, Sustain. Water Resourc. Manag. 2016, 2, 71-86. [CrossRef]

14. Muselli, M.; Beysens, D.; Marcillat, J.; Milimouk, I.; Nilsson, T.; Louche, A. Dew water collector for potable water in Ajaccio (Corsica Island, France). Atmos. Res. 2002, 64, 297-312. [CrossRef] 
15. Beysens, D.; Milimouk, I.; Nikolayev, V.; Muselli, M.; Marcillat, J. Using radiative cooling to condense atmospheric vapor: A study to improve water yield. J. Hydrol. 2003, 276, 111. [CrossRef]

16. Beysens, D.; Muselli, M.; Nikolayev, V.; Narhe, R.; Milimouk, I. Measurement and modelling of dew in island, coastal and alpine areas. Atmos. Res. 2005, 73, 122. [CrossRef]

17. Clus, O.; Ortega, P.; Muselli, M.; Milimouk, I.; Beysens, D. Study of dew water collection in humid tropical islands. J. Hydrol. 2008, 361, 159-171. [CrossRef]

18. Muselli, M.; Beysens, D.; Mileta, M.; Milimouk, I. Dew and rain water collection in the Dalmatian Coast, Croatia. Atmos. Res. 2009, 92, 455-463. [CrossRef]

19. Leopold, L.B. Dew as a source of plant moisture. Pac. Sci. 1952, 6, 259-261.

20. Kidron, G.J. Altitude dependent dew and fog in the Negev Desert, Israel. Agric. For. Meteorol. 1999, 96, 1-8. [CrossRef]

21. Alnaser, W.E.; Barakat, A. Use of condensed water vapour from the atmosphere for irrigation in Bahrain. Appl. Energy 2000, 65, 318. [CrossRef]

22. Agam, N.; Berliner, P.R. Dew formation and water vapor adsorption in semiarid environments-A review. J. Arid Environ. 2006, 65, 572-590. [CrossRef]

23. Sharan, G.; Shah, R.; Millimouk-Melnythouk, I.; Beysens, D. Roofs as Dew Collectors: Corrugated Galvanized Iron Roofs in Kothara and Suthari (NW India). In Proceedings of the Fourth International Conference on Fog, Fog Collection and Dew, La Serena, Chile, 22-27 July 2007.

24. Richards, K. Observation and simulation of dew in rural and urban environments. Prog. Phys. Geogr. 2004, 28, 76-94. [CrossRef]

25. Beysens, D.; Ohayon, C.; Muselli, M.; Clus, O. Chemical and biological characteristics of dew and rain water in an urban coastal area (Bordeaux, France). Atmos. Environ. 2006, 40, 3710-3723. [CrossRef]

26. Ye, Y.; Zhou, K.; Song, L.; Jin, J.; Peng, S. Dew amount and its correlation with meteorological factors in urban landscapes of Guangzhou, China. Atmos. Res. 2007, 86, 21-29. [CrossRef]

27. Hussein, T.; Sogacheva, L.; Petaja, T. Accumulation and coarse modes particle concentration during dew formation and precipitation. Aerosol Air Qual. Res. 2018, 18, 2929-2938. [CrossRef]

28. Odeh, I.; Arar, S.; Al-Hunaiti, A.; Sa'aydeh, H.; Hammad, G.; Duplissy, J.; Vuollekoski, H.; Korpela, A.; Petäjä, T.; Kulmala, M.; et al. Chemical investigation and quality of urban dew collection with dust precipitation. Environ. Sci. Pollut. Res. 2017, 24, 12312-12318. [CrossRef]

29. Vuollekoski, H.; Vogt, M.; Sinclair, V.A.; Duplissy, J.; Järvinen, H.; Kyrö, E.; Makkonen, R.; Petäjä, T.; Prisle, N.L.; Räisänen, P.; et al. Estimates of global dew collection potential on artificial surfaces. Hydrol. Earth Syst. Sci. 2015, 19, 601-613. [CrossRef]

30. Alizadeh, A. Principles of Applied Hydrology; Iman Reza University: Mashhad, Iran, 2011.

31. Esfandiarnejad, A.; Ahangar, R.; Kamalian, U.R.; Sangchouli, T. Feasibility studies for water harvesting from fog and atmospheric moisture. In Proceedings of the Hormozgan Coastal Zone (South of Iran). 5th International Conference on Fog, Fog Collection and Dew, Munster, Germany, 25-30 July 2010.

32. Davtalab, R.; Salamat, A.; Oji, R. Water harvesting from fog and air humidity in the warm and coastal regions in the south of Iran. Irrig. Drain. 2013, 6, 281-288. [CrossRef]

33. Notaro, M.; Yu, Y.; Kalashnikova, O.V. Regime shift in Arabian dust activity, triggered by persistent Fertile Crescent drought. J. Geophys. Res. Atmos. 2015, 10, 229. [CrossRef]

34. Rezazadeh, M.; Irannejad, P.; Shao, Y. Climatology of the Middle East dust events. Aeol. Res. 2013, 10, 103-109. [CrossRef]

35. Satheesh, S.K.; Deepshikha, S.; Srinivasan, J. Impact of dust aerosols on Earth-atmosphere clear-sky albedo and its short wave radiative forcing over African and Arabian regions. Int. J. Remote Sens. 2006, 27, 1691-1706. [CrossRef]

36. Givati, A.; Rosenfeld, D. Possible impacts of anthropogenic aerosols on water resources of the Jordan River and the Sea of Galilee. Water Ressour. Res. 2007, 43, W10419. [CrossRef]

37. Berrisford, P.; Dee, D.; Poli, P.; Brugge, R.; Fielding, K.; Fuentes, M.; Kallberg, P.; Kobayashi, S.; Uppala, S.; Simmons, A. ERA report series. In The ERA-Interim Archive; ECMWF: Reading, UK, 2011; Volume 2.

38. Dee, D.P.; Uppala, S.M.; Simmons, A.J.; Berrisford, P.; Poli, P.; Kobayashi, S.; Andrae, U.; Balmaseda, M.A.; Balsamo, G.; Bauer, P.; et al. The ERA-Interim reanalysis: Configuration and performance of the data assimilation system. Q. J. R. Meteorol. Soc. 2011, 137, 553-597. [CrossRef] 
39. Tampkins, A. A Brief Introduction1 to Retrieving ERA Interim via the Web and Webapi; ECMWF: Reading, UK, 2017.

40. Evenari, M. The Negev: The Challenge of a Desert; Harvard University Press: Cambridge, MA, USA, 1982.

41. Jacobs, A.F.; Heusinkveld, B.G.; Berkowicz, S.M. Dew measurements along a longitudinal sand dune transect, Negev Desert, Israel. Int. J. Biometeorol. 2000, 43, 184-190. [CrossRef] [PubMed]

42. Zangvil, A. Six years of dew observations in the Negev Desert, Israel. J. Arid Environ. 1996, 32, 361-371. [CrossRef]

43. Tomaszkiewicz, M.; Abou Najm, M.; Zurayk, R.; El-Fadel, M. Dew as an adaptation measure to meet water demand in agriculture and reforestation. Agric. For. Meteorol. 2017, 232, 411-421. [CrossRef]

44. Hanisch, S.; Lohrey, C.; Buerkert, A. Dewfall and its ecological significance in semi-arid coastal south-western Madagascar. J. Arid Environ. 2015, 121, 24-31. [CrossRef]

45. Meunier, D.; Beysens, D. Dew, fog, drizzle and rain water in Baku (Azerbaijan). Atmos. Res. 2016, 178-179, 65-72. [CrossRef]

46. Hao, X.-M.; Li, C.; Guo, B.; Ma, J.-X.; Ayup, M.; Chen, Z.-S. Dew formation and its long-term trend in a desert riparian forest ecosystem on the eastern edge of the Taklimakan Desert in China. J. Hydrol. 2012, 472-473, 90-98. [CrossRef]

47. Gaiek, G.; Sobik, M.; Blas, M.; Polkowska, Z.; Cichala-Kamrowska, K. Dew Formation and Chemistry Near a Motorway in Poland. Pure Appl. Geophys. 2012, 169, 1053-1066. [CrossRef]

48. Nilsson, T. Initial experiments on dew collection in Sweden and Tanzania. Solar Energy Mater. Solar Cells 1996, 40, 23-32. [CrossRef]

49. Beysens, D.; Muselli, M.; Milimouk, I.; Ohayone, C.; Berkowicz, S.M.; Soyeuxg, E.; Mileta, M.; Ortega, P. Application of passive radiative cooling for dew condensation. Energy 2006, 31, 1967-1979. [CrossRef]

50. Muselli, M.; Beysens, D.; Milimouk, I. A comparative study of two large radiative dew water condensers. J. Arid Environ. 2006, 64, 54-76. [CrossRef]

51. Takenaka, N.; Soda, H.; Sato, K.; Terada, H.; Suzue, T.; Bandow, H.; Maeda, Y. Difference in amounts and composition of dew from different types of dew collectors. Water Air Soil Poll. 2003, 147, 51-60. [CrossRef]

52. Berkowicz, S.M.; Beysens, D.; Milimouk, I.; Heusinkveld, B.G.; Muselli, M.; Wakshal, E.; Jacobs, A.F.G. Urban dew collection under semi-arid conditions: Jerusalem. In Proceedings of the 3rd International Conference on Fog, Fog Collection and Dew 2004, Cape Town, South Africa, 11-15 October 2014; p. 4.

53. Berkowicz, S.M.; Beysens, D.; Milimouk-Melnytchouk, I.; Heusinkveld, B.G.; Muselli, M.; Jacobs, A.F.G.; Clus, O. Urban dew collection in Jerusalem: A three-year analysis. In Proceedings of the 4th International Conference on Fog, Fog Collection and Dew 2007, La Serena, Chile, 23-27 July 2007; pp. 297-300.

54. Mileta, M.; Muselli, M.; Beysens, D.; Milimouk, I.; Berkowicz, S.; Heusinkveld, B.G.; Jacobs, A.F.G. Comparison of dew yields in four Mediterranean sites: Similarities and differences. In Proceedings of the 3rd International Conference on Fog, Fog Collection and Dew 2004, Cape Town, South Africa, 11-15 October 2004; p. E2.

55. Jacobs, A.F.G.; Heusinkveld, B.G.; Berkowicz, S.M. Passive dew collection in a grassland area, The Netherlands. Atmos. Res. 2008, 87, 377-385. [CrossRef]

56. Lekouch, I.; Kabbachi, B.; Milimouk-Melnytchouk, I.; Muselli, M.; Beysens, D. Influence of temporal variations and climatic conditions on the physical and chemical characteristics of dew and rain in South-West Morocco. In Proceedings of the 5th International Conference on Fog, Fog Collection and Dew 2010, Münster, Germany, 25-30 July 2010; pp. 43-46.

57. Sobik, M.; Błas', M.; Polkowska, Z. Climatology of dew in Poland. In Proceedings of the 5th International Conference on Fog, Fog Collection and Dew 2010, Münster, Germany, 25-30 July 2010; not reviewed abstract, 78 .

58. Sharan, G.; Clus, O.; Singh, S.; Muselli, M.; Beysens, D. A very large dew and rain ridge collector in the Kutch area (Gujarat, India). J. Hydrol. 2011, 405, 171-181. [CrossRef]

(C) 2019 by the authors. Licensee MDPI, Basel, Switzerland. This article is an open access article distributed under the terms and conditions of the Creative Commons Attribution (CC BY) license (http://creativecommons.org/licenses/by/4.0/). 